Revue d'histoire de l'Amérique française

ZRS REVUE D.HISTOIRE DE L'AMÉRIQUE FRANÇAISE

\title{
Choix d'ouvrages traitant de la critique et des méthodes historiques (suite)
}

\section{Marie-Claire Daveluy}

Volume 18, numéro 1, juin 1964

URI : https://id.erudit.org/iderudit/302356ar

DOI : https://doi.org/10.7202/302356ar

Aller au sommaire du numéro

Éditeur(s)

Institut d'histoire de l'Amérique française

ISSN

0035-2357 (imprimé)

1492-1383 (numérique)

Découvrir la revue

Citer ce document

Daveluy, M.-C. (1964). Choix d'ouvrages traitant de la critique et des méthodes historiques (suite). Revue d'histoire de l'Amérique française, 18(1), 161-161.

https://doi.org/10.7202/302356ar d'utilisation que vous pouvez consulter en ligne.

https://apropos.erudit.org/fr/usagers/politique-dutilisation/ 


\section{BIBLIOGRAPHIE}

\section{CHOIX D'OUVRAGES TRAITANT DE LA CRITIQUE} ET DES MÉTHODES HISTORIQUES

$$
\text { (suite)* }
$$

IV - Sur les sciences auxiliaires de l'histoire et divers autres ouvrages.

53. De Genouillac Gourdon, L'Art héraldique. Paris, 1889.

54. Charles-Victor LANGLoIs et Charles SEIGNoBos, Introduction aux études historiques. 2e édition. Paris, Hachette, 1898. XVIII - 308 pages. In-12.

55. Charles-Victor LANGLOIS, Manuel de bibliographie historique. 4e édition. Paris, Hachette, 1901-1904. XI - 623 pages. In-12.

56. Camille ENLART, Manuel d'archéologie française. Paris, 1902-1932.

57. A. Сrm, Le Livre. Paris, Flammarion, 1905-1908. 5 vol. - 1907-1953 -

58. Fernand CABRoL, Dictionnaire d'archéologie chrétienne et de liturgie. Paris, Letouzey et Ané, 1907-1953. 156 vol. (176 fascicules).

$$
-1909-1950 \text { - }
$$

59. VACANT et MANGENot, Dictionnaire de théologie catholique. Paris, Letouzey et Ané, 1909-1950. 15 vol.

$$
\text { -1912-1914 - }
$$

60. Monseigneur Alfred BAUDRILlARD, Dictionnaire d'histoire et de géographie ecclésiastiques. Paris, Letouzey et Ané, 19121914.

61. Roman, Manuel de sigillographie. Paris, 1913.

62. Arthur GIRY, Manuel de diplomatique. Paris, 1914 ; rééd., 2 vol., 1925.

63. Maurice Prou, Manuel de paléographie latine et française. 4e édition. Paris, Picard, 1924. 403 p. In-12.

64. Alain DE BOUARD, Manuel de diplomatique française et pontificale. 1 vol. et 1 album. Paris, 1929.

* Voir notre Revue, XVII : 456-463, 605-611.

\section{MARIE-Claire DaVeluY}

